\title{
Comparison of Rhizon Sampling and Whole Round Squeezing for Marine Sediment Porewater
}

\author{
by Heather N. Schrum, Richard W. Murray, and Britta Gribsholt
}

doi:10.2204/iodp.sd.13.08.2011

\section{Introduction}

The collection and chemical analysis of sedimentary porewater is central to many marine studies. Porewater alkalinity, dissolved inorganic carbon (DIC), sulfate, nitrate, and other dissolved ions are used to identify and determine rates of geochemical reactions and microbial respiration pathways, such as sulfate reduction and denitrification (Froelich et al., 1979; Berner, 1980; Gieskes et al., 1986; D’Hondt et al., 2004; Schulz, 2006; Martin and Sayles, 2007). Ammonium is critical for understanding microbial respiration and the nitrogen cycle (Blackburn, 1988). Chloride is used to reconstruct ocean salinity variations, constrain flow rates, and estimate gas hydrate concentrations (Paull et al., 1996; Adkins et al., 2002; Spivack et al., 2002). Each of these studies requires the recovery of porewater that is not compromised by sampling artifacts.

A number of methods are used to extract fluids from sediments. Here we report our experimental comparison of two methods used by the Integrated Ocean Drilling Program (IODP): extraction with Rhizon samplers and sediment squeezing (Seeberg-Elverfeldt et al., 2005; Manheim and Sayles, 1974).
Rhizon samplers are inserted directly into an intact sediment core; they collect porewater by vacuum filtration through a thin porous tube attached to a syringe (Seeberg-Elverfeldt et al., 2005; Dickens et al., 2007). Rhizons allow for high-resolution sampling because they may be spaced as closely as $2-3 \mathrm{~cm}$ apart. They also only minimally mechanically disturb the sediment and are typically time efficient. Porewater and soil moisture studies report that Rhizon sampling produces accurate results for dissolved ammonium, sulfate, chloride, and iron (Gribsholt and Kristensen, 2002; Song et al., 2003; Seeberg-Elverfeldt et al., 2005; Backman et al., 2006; Dickens et al., 2007). A disadvantage of Rhizon sampling is that it is often restricted to the upper portion of the sediment column (tens of meters, depending on lithology), where sediment is not too compacted. Also, the partial vacuum may lead to significant sampling artifacts for certain chemical species.

Whole round squeezing mechanically pressurizes a sediment sample, forcing the porewater through a sampling port. Squeezing has been shown to effectively collect porewater to depths of $\sim 1600$ m below seafloor (Saffer et al., 2010). Whole round squeezing also minimizes the contact of porewater with air. The disadvantages of squeezing include pressure-related additions through the destruction of particulate detritus or microbial cells (Bollinger et al., 1992), oxygen contamination (Robbins and Gustinis, 1976), and temperature artifacts (Bischoff et al., 1970; Fanning and Pilson, 1971). Many of these have been studied, however, and were deemed minimal (Gieskes, 1974). Dickens et al. (2007) compared Rhizon and squeezing methods for a suite of dissolved chemicals and concluded that the chemical concentrations did not vary significantly between methods.

We evaluated the use of Rhizon sampling and whole round squeezing for analyzing alkalinity, DIC, ammonium, sulfate, chloride, and nitrate in porewater from equatorial and South Pacific sites. In these experiments we directly compared the dissolved species collected by both methods in the same core and/or location and used these data to interpret potential sampling artifacts. 


\section{Materials and Procedures}

We collected porewater from five sites in the Pacific Ocean with variable amounts of clay and biogenic ooze. At Site SPG-9 in the South Pacific Gyre we compared the Rhizon and squeezing method for alkalinity from sediment retrieved by a multi-core system, and we compared the porewater extraction methods for alkalinity and DIC from a gravity core at the Pacific Site EQP-9 (Fig. 1).

DIC, alkalinity, ammonium, sulfate, and chloride were measured from gravity cores at EQP-1, EQP-6, and EQP-6A (Fig. 2). Ammonium concentrations were compared for both extraction methods from samples at EQP-1. Two separate gravity cores at EQP- 6 and -6 A were retrieved at nearly the same location, and they have nearly identical lithologies. We compared both porewater extraction methods for sulfate and chloride at these two sites.

For SPG and EQP sites, Rhizon CSS-F 5-cm core solution samplers with $0.1 \mu \mathrm{m}$ microporous filters were used to collect porewater. The squeezing apparatus and method on both cruises were identical to those used by the Ocean Drilling Program (ODP) and Integrated Ocean Drilling Program (IODP) (see Methods in Backman et al., 2006).

For SPG and EQP samples, we measured alkalinity by Gran-titration following Gieskes et al. (1991). DIC was measured by acid extraction and infrared measurement of purged $\mathrm{CO}_{2}$. Sulfate, chloride, and nitrate were quantified by ion chromatography. Dissolved ammonium was determined spectrophotometrically based on Solórzano (1969).

\section{Comparative Assessment of Rhizon and Squeezing Protocols}

At SPG-9 and EQP-9, alkalinities from porewater collected by Rhizon sampling are consistently lower than those measured from squeezed samples by approximately $0.8 \mathrm{mM}$ and $0.06 \mathrm{mM}$, respectively. At EQP-9, DIC concentrations from Rhizons are approximately $0.06 \mathrm{mM}$ on average less than squeezed concentrations (Fig. 1). These differences in alkalinity and DIC are larger than can be explained by analytical uncertainty.

Alkanity and DIC concentrations collected by Rhizon sampling have more scatter at SPG-9 and EQP-9. Rhizon alkalinities ranges from $1.64-2.02 \mathrm{mM}$ and $2.37-2.52 \mathrm{mM}$ at SPG-9 and EQP-9, respectively, while squeezed alkalinities range from $2.53-2.69 \mathrm{mM}$ and $2.42-2.56 \mathrm{mM}$ at these respective sites. Rhizon DIC values ranges from $2.25-2.41 \mathrm{mM}$ versus $2.38-2.46 \mathrm{mM}$ for squeezed samples at EQ-9.
In contrast to these findings, measured concentrations of ammonium, sulfate, and chloride are all within the error of the analytical methods, for both squeezing and Rhizon extraction at EQP-1, and EQP-6 and -6A (Fig. 3). This is consistent with results from Dickens et al. (2007) and Backman et al. (2006).

While neither the squeezing nor the Rhizon method for porewater extraction showed measurable sampling artifacts for ammonium, sulfate, and chloride, during the equatorial Pacific expedition we found repeated evidence that the squeezing method introduced nitrate contamination on the scale of tens of micromoles. We suspect that the Whatman \#1 paper filters used inside the squeezer contained trace amounts of nitrate that were not removed even after soaking the filters in $18 \mathrm{MOhm}$ water for $\sim 24$ hours and allowing them to dry. We filtered $18 \mathrm{MOhm}$ water through the squeezer and found that a nitrate blank was present. Pressure-related destruction of cells may also have contributed to nitrate contamination during squeezing. Risgaard-Petersen et al. (2006) showed that there are considerable amounts of nitrate stored in foraminifera. These concentrations ( $60 \mathrm{nmol} \mathrm{cm}{ }^{-3}$ sediment) may not fully explain the contamination but may contribute to the erroneous nitrate values.

\section{Discussion}

Vacuum filtration is commonly used for fluid degassing. During Rhizon sampling into a low pressure headspace, subatmospheric pressure creates a pressure differential that forces the porewater through the filter. The filter creates a flow disturbance, causing minute bubbles of entrained gas to coalesce or to break the fluid into small droplets to provide a large surface-to-volume ratio for enhancing the effect of the vacuum degassing the fluid (Chambers et al., 1998). 
$\mathrm{CO}_{2}$ degassing during Rhizon sample extraction leads to alkalinity and DIC concentrations that are consistently lower than squeezed sample concentrations (Fig. 1). $\mathrm{CO}_{2}$ degassing drives an increase in carbonate ion concentration, which increases the tendency for calcium car-bonate to precipitate, thereby decreasing alkalinity. In contrast, whole round squeezing applies pressure to the sediment sample, pushing the porewater out of the sediment into the filter-capped syringe, and it should have minimal impact on the carbonate system during sampling. It is possible, however, that pressure-related destruction of cells may cause some carbonate contamination during squeezing. When squeezing is used for sample extraction, care should be taken to store whole rounds at in situ temperature prior to squeezing, as carbonate saturation has retrograde solubility, and cation exchange between clay minerals and interstitial water is temperature dependent (Bischoff et al., 1970; Masuzawa et al., 1980).

The increased scatter in the alkalinity and DIC concentrations collected by Rhizon sampling also indicates compromised data. Based on visual inspection, if these concentrations were taken as true values, the data would lead to unrealistic concentration gradients in the sediment with improbable fluxes and rapidly changing sources and sinks (Fig. 1).

Our alkalinity results are not consistent with Backman et al. (2006), who convincingly reported no significant difference in alkalinity between samples collected by Rhizon and whole round squeezing. The differences in our findings are possibly due to sediment composition and porewater carbonate concentrations. Dissolved calcium carbonate concentrations are higher at most of the Pacific sites than in Arctic sediment collected by Backman et al. Porewater degassing during Rhizon sampling likely caused relatively greater calcium carbonate precipitation, which led to a greater decrease in alkalinity compared to squeezed samples. This is also the likely explanation for the greater difference in alkalinity concentrations between the Rhizon and squeezed samples at SPG-9 compared to EQP-9 (Fig. 1).

\section{Recommendations}

Our study shows that a combined sampling protocol of Rhizon sampling for ammonium (this study and Backman et al., 2006), nitrate, and metals (e.g., Mn, Backman et al., 2006) and squeezing for alkalinity, DIC, and $\mathrm{pH}$ will lead to a complete characterization of the dissolved chemical species in multiple environments. Future scientific coring and drill- ing expeditions that rely on high precision chemical profiles in marine sediment would greatly benefit from this combined sampling protocol.

While Seeberg-Elverfeldt et al. (2005) suggest that $\mathrm{pH}$ may be a viable measurement from Rhizon samplers, we argue that the degassing of $\mathrm{CO}_{2}$ by Rhizons will produce higher than realistic $\mathrm{pH}$ and should be avoided. In this context, critical differences between soil systems and marine sediments appear to compromise comparison between soil-based and sediment-based studies. It is important that Rhizon samplers are employed to collect porewater that will be used to measure nitrate, as squeezing potentially introduces nitrate contamination on the scale of tens of micromoles.

\section{Acknowledgements}

We thank the captains and crew of the R/V Roger Revelle and R/V Knorr, and the Knox-02RR (South Pacific Gyre) and KNR 195-3 (equatorial Pacific) shipboard science party members. Special thanks to Steven D'Hondt and Arthur Spivack for their support and helpful comments and to Timothy Ferdelman, Benjamin Brunner, and Dennis Graham for fruitful conversations, sample collection, and chemical analyses. This project was funded by the NSF Biological Oceanography Program and the Integrated Ocean Drilling Program.

\section{References}

Adkins, J.F., McIntyre, K., and Schrag, D.P., 2002. The salinity, temperature, and $\delta^{18} \mathrm{O}$ of the glacial deep ocean. Science, 298:1769-1773, doi:10.1126/science.1076252. 
Backman, J., Moran, K., McInroy, D.B., Mayer, L.A., and the Expedition 302 Scientists., 2006. Proc. IODP, 302: Washington, DC (Integrated Ocean Drilling Program Management International, Inc.).

Berner, R.A., 1980. Early Diagenesis: A Theoretical Approach: Princeton, NJ (Princeton University Press)

Bischoff, J.L., Greer, R.E., and Luistro, A.O., 1970. Composition of interstitial waters of marine sediments: Temperature of squeezing effect. Science, 167(3922):1245-1246, doi:10.1126/science.167.3922.1245.

Blackburn, T.H., 1988. Chapter 8: Benthic mineralization and bacterial production, In Blackburn, T.H., and Sørensen, J. (Eds.), Nitrogen Cycling in Coastal Marine Environments: Chichester (John Wiley and Sons), 175-190.

Bollinger, R., Brandl, H., Höhener, P., Hanselmann, K.W., and Bachofen, R., 1992. Squeeze-water analysis for the determination of microbial metabolites in lake sediment Comparison of methods. Limnol. Oceanogr., 37:448-455, doi:10.4319/10.1992.37.2.0448.

Chambers, A., Fitch, R.K., and Halliday, B.S., 1998. Basic Vacuum Technology, second edition: London (Institute of Physics Publ.), doi:10.1201/NOE0750304955.

D’Hondt, S., Jørgensen, B.B., Miller, D.J., Batzke, A., Blake, R., Cragg, B.A., Cypionka, H., et al., 2004. Distributions of microbial activities in deep subseafloor sediments. Science, 30:2216-2221, doi:10.1126/science.1101155.

Dickens, G.R., Koelling, M., Smith, D.C., Schneiders, L., and the IODP Expedition 302 Scientists, 2007. Rhizon sampling of pore waters on scientific drilling expeditions: An example from the IODP Expedition 302, Arctic Coring Expedition (ACEX). Sci. Drill., 4:22-25.

Fanning, K.A., and Pilson, M.E.Q., 1971. Interstitial silica and pH in marine sediments: Some effects of sampling procedures. Science, 173:1228-1231, doi:10.1126/science.173.4003. 1228.

Froelich, P.N., Klinkhammer, G.P., Bender, M.L., Luedtke, N.A., Heath, G.R., Cullen, D., Dauphin, P., Hammond, D., Hartman, B., and Maynard, V., 1979. Early oxidation of organic matter in pelagic sediments of the eastern equatorial Atlantic: Suboxic diagenesis. Geochim. Cosmochim. Acta, 43:1075-1090.

Gieskes, J.M., 1974. Interstitial water studies, Leg 25. In Simpson, E.S.W., Schlich, R., et al., Init. Repts. DSDP, 25: Washington, DC (U.S. Govt. Printing Office), 361-394.

Gieskes, J.M., Kastner, M., Erzinger, J., Boulegue, J., and Hart, S.R., 1986. Geochemical studies Hole 504B, Leg 92. In Leinen, M., Rea, D.K., et al., Init. Repts. DSDP, 92: Washington, DC (U.S. Govt. Printing Office), 547.

Gieskes, J.M., Gamo, T., and Brumsack, H., 1991. Chemical methods for interstitial water analysis aboard JOIDES Resolution. ODP Tech. Note, 15 .

Gribsholt, B., and Kristensen, E., 2002. Impact of sampling methods on sulfate reduction rates and dissolved organic carbon (DOC) concentrations in salt marsh sediment. Wetlands Ecol. Manage., 10:371-379, doi:10.1023/A:1020940314010.

Manheim, F.T., and Sayles, F.L., 1974. Composition and origin of interstitial waters of marine sediments, based on deep sea drill cores. In Goldberg, E.D. (Ed.), The Sea (Vol. 5): Marine Chemistry: The Sedimentary Cycle. New York (WileyInterscience), 527-568.
Martin, W.R., and Sayles, F.L., 2007. The recycling of biogenic material at the seafloor. In Mackenzie, F.T. (Ed.), Treatise on Geochemistry. Vol. 7: Sediments, Diagenesis, and Sedimentary Rocks: Oxford (Elsevier Science), 37-65.

Masuzawa, T., Kanamori, S., and Kitano, Y., 1980. The reversible effect of temperature on the chemical composition of interstitial water of marine sediment. J. Oceanogr. Soc. Jpn., 36:68-72, doi:10.1007/BF02209357.

Paull, C.K., Matsumoto, R., Wallace, P.J., and Expedition 164 Scientists, 1996. Proc. ODP, Init. Repts., 164: College Station, TX (Ocean Drilling Program).

Risgaard-Petersen, N., Langezaal, A.M., Ingvardsen, S., Schmid, M.C., Jetten, M.S.M., Op den Camp, H.J.M., Derksen, J.W.M., et al., 2006. Evidence for complete denitrification in a benthic foraminifer. Nature, 443:93-96, doi:10.1038/ nature 05070 .

Robbins, J.A., and Gustinis, J., 1976. A squeezer for efficient extraction of pore water from small volumes of anoxic sediment. Limnol. Oceanogr., 21:905-909, doi:10.4319/1o.1976. 21.6.0905.

Saffer, D., McNeill, L., Byrne, T., Araki, E., Toczko, S., Eguchi, N., Takahashi, K., and the Expedition 319 Scientists, 2010. Proc. IODP, 319: Tokyo (Integrated Ocean Drilling Program Management International, Inc.).

Schulz, H.D., 2006. Quantification of early diagenesis: Dissolved constituents in pore water and signals in the solid phase. In Schulz, H.D., and Zabel, M. (Eds.), Marine Geochemistry, second edition: Berlin (Springer-Verlag), 73-124.

Seeberg-Elverfeldt, J., Schlüter, M., Feseker, T., and Kölling, M., 2005. Rhizon sampling of porewater near the sedimentwater interface of aquatic systems. Limnol. Oceanogr.: Methods, 3:361-371, doi:10.4319/1om.2005.3.361.

Solórzano, L., 1969. Determination of ammonia in natural waters by the phenolhypochlorite method. Limnol. Oceanogr., 14:799-801, doi:10.4319/10.1969.14.5.0799.

Song, J., Luo, Y.M., Zhao, Q.G., and Christie, P., 2003. Novel use of soil moisture samplers for studies on anaerobic ammonium fluxes across lake sediment-water interfaces. Chemosphere, 50(6):711-715, doi:10.1016/S0045-6535(02)00210-2.

Spivack, A.J., Kastner, M., and Ransom, B., 2002. Elemental and isotopic chloride geochemistry and fluid flow in the Nankai Trough. Geophys. Res. Lett., 29:1661-1665, doi:10.1029/ 2001GL014122.

\section{Authors}

Heather N. Schrum, Massachusetts Maritime Academy, 101 Academy Drive, Buzzards Bay, MA 02532, U.S.A., e-mail: hschrum@maritime.edu

Richard W. Murray, Department of Earth Sciences, Boston University, 1 Silber Way, Boston, MA 02215, U.S.A.

Britta Gribsholt, Department of Biological Sciences, Center for Geomicrobiology, University of Aarhus, Ny Munkegade 114, DK-8000 Aarhus C, Denmark. 